\title{
Development of Antimicrobial Antibodies: A Novel Line of Attack in the Battle Against Infection
}

\section{Alwyn Rapose*}

Department of Medicine, University of Massachusetts Medical School, Worcester, MA, USA

Staphylococcus aureus is a common cause of severe infections in hospitalized patients [1]. The spectrum of disease varies from necrotizing skin and soft tissue infection to bacteremia, endocarditis and pneumonia [2]. Staphylococcal infection is also a feared complication in patients with prosthetic materials like artificial joints [3], cardiac support devices [4] and hemodialysis catheters [5].

In addition, $S$. aureus is now commonly associated with skin infection as well as pneumonia in patients in the community [6-8].

Staphylococcus infections are caused either by methicillin sensitive Staphylococcus aureus (MSSA) in which case treatment options include the use of beta lactams, or methicillin-resistant Staphylococcus aureus (MRSA) in which case the "gold standard" for treatment of severe infection is the drug vancomycin. Other antibiotics used in the treatment of staphylococcal infection include clindamycin, bactrim, quinolones, tetracyclines and rifampin.

There is now an increasing incidence of failure in spite of optimized dosing of the "gold standard". This can be attributable to increased vancomycin minimum inhibitory concentrations (MICs) of $S$. aureus $[9,10]$. Along with this, potential adverse effects including nephrotoxicity attributable to vancomycin, has resulted in research into new antibiotics against MRSA and development of products like linezolid [11], daptomycin [12], tigecycline [13] and ceftaroline [14]. Linezolid is considered a bacterostatic agent, while daptomycin is considered bactericidal. As expected, with increasing use of these products there are now reported cases of treatment failure even with high dose daptomycin [15] as well as linezolid [16] and ceftaroline [17].

The use of systemic antibiotics targeting $S$. aureus is also associated with "collateral damage". These antibiotics act against not only the $S$. aureus, but also cause disruption in host bacterial flora resulting in secondary infectious complications. The most common example of this is the development of Clostridium difficile infection and diarrhea [18].

Therefore there is an urgent need for development of new antimicrobial products against $S$. aureus.

In this issue of the Journal of Vaccine and Vaccination, Vaillant et al present very important research into "non-antibiotic" therapy for staphylococcal infections. S. aureus synthesizes protein A (SpA) which plays an important role in bacterial adhesion and has been demonstrated to be responsible for a cascade of reactions that help bacterial invasion of host tissue [19]. The authors used chicks to develop antibody to SpA. They showed that the antibody was able to inhibit the growth of $S$. aureus, thus demonstrating the antimicrobial properties of this product. This novel approach - targeted antibodies - in the battle against $S$. aureus infections is very important for a number of reasons: there is increased incidence of antibiotic resistance as mentioned above, there are significant side effects associated with high dose and prolonged antibiotic therapy for resistant infections, and increasing number of patients who present with allergies to multiple antibiotics. In addition, targeted therapy will hopefully reduce risk of collateral damage and hence $C$. difficile infection.
The use of the immune system in the prevention of infection is not a new concept. Oral typhoid and polio vaccines are examples of the use of agents in the prevention of bacterial and viral infections respectively. Use of monoclonal antibody targeting bacterial toxin is one of the new modalities in the treatment of $C$. difficile infection [20]. Important advantages of the authors' research include oral route of administration and non-live nature of this product.

One cautionary note is worth bringing up at this time. There are a number of patients who claim egg allergy, and though safety of vaccines has been demonstrated [21], this has been a stumbling block in the use of a number of vaccines in these patients. This may also prove to be a limiting factor in terms of human use of a product developed using chick embryo.

However we look forward for further developments and standardization of this exciting potential antimicrobial product. I convey to the authors wholehearted wishes for successful outcomes into this translational research.

\section{References}

1. Kallen AJ, Mu Y, Bulens S, Reingold A, Petit S, et al. (2010) Health CareAssociated Invasive MRSA Infections, 2005-2008. JAMA 304: 641-648.

2. Klevens RM, Morrison MA, Nadle J, Petit S, Gershman K, et al. (2007) Invasive Methicillin-Resistant Staphylococcus aureus Infections in the United States. JAMA 298: 1763-1771.

3. Parvizi J, Azzam K, Ghanem E, Austin MS, Rothman RH (2009) Periprosthetic Infection due to Resistant Staphylococci: Serious Problems on the Horizon. Clin Orthop Relat Res 467: 1732-1739.

4. Tarakji KG, Chan EJ, Cantillon DJ, Doonan AL, Hu T, et al. (2010) Cardiac Implantable Electronic Device Infections: Presentation, Management, and Patient Outcomes. Heart Rhythm 7: 1043-1047.

5. Al-Solaiman $Y$, Estrada $E$, Allon $M$ (2011) The spectrum of infections in Catheter-Dependent Hemodialysis Patients. Clin J Am Soc Nephrol 6: 2247 2252.

6. Karamatsu ML, Thorp AW, Brown L (2012) Changes in Community-Associated Methicillin-Resistant Staphylococcus aureus Skin and Soft Tissue Infections presenting to the Pediatric Emergency Department: Comparing 2003 to 2008. Pediatr Emerg Care 28: 131-135.

7. Orscheln RC, Hunstad DA, Fritz SA, Loughman JA, Mitchell K, et al. (2009) Contribution of Genetically-Restricted, Methicillin-Susceptible Strains to the Ongoing Epidemic of Community-Acquired Staphylococcus aureus Infections. Clin Infect Dis 49: 536-542.

Corresponding author: Alwyn Rapose, MD, Assistant Professor of Clinical Medicine, Department of Medicine, University of Massachusetts Medical School, Worcester, MA, USA, E-mail: Alwyn.Rapose@reliantmedicalgroup.org

Received March 25, 2012; Accepted March 26, 2012; Published March 28, 2012

Citation: Rapose A (2012) Development of Antimicrobial Antibodies: A Novel Line of Attack in the Battle Against Infection. J Vaccines Vaccin 3:e103. doi:10.4172/2157 $7560.1000 \mathrm{e} 103$

Copyright: (c) 2012 Rapose A. This is an open-access article distributed unde the terms of the Creative Commons Attribution License, which permits unrestricted use, distribution, and reproduction in any medium, provided the original author and source are credited. 
Citation: Rapose A (2012) Development of Antimicrobial Antibodies: A Novel Line of Attack in the Battle Against Infection. J Vaccines Vaccin 3:e103. doi:10.4172/2157-7560.1000e103

8. Moran GJ, Krishnadasan A, Gorwitz RJ, Fosheim GE, Albrecht V, et al. (2012) Prevalence of Methicillin-Resistant Staphylococcus aureus as an Etiology of Community-Acquired Pneumonia. Clin Infect Dis 54: 1126-1133.

9. Lodise TP, Graves J, Evans A, Graffunder E, Helmecke M, et al. (2008) Relationship between Vancomycin MIC and Failure among Patients with Methicillin-Resistant Staphylococcus aureus Bacteremia Treated with Vancomycin. Antimicrob Agents Chemother 52: 3315-3320.

10. Hidayat LK, Hsu DI, Quist R, Shriner KA, Wong-Beringer A (2006) High Dose Vancomycin Therapy Methicillin-Resistant Staphylococcus aureus Infections: Efficacy and Toxicity. Arch Intern Med. 166: 2138-2144

11. Wunderink RG, Niederman MS, Kollef MH, Shorr AF, Kunkel MJ, et al. (2012) Linezolid in Methicillin-Resistant Staphylococcus aureus Nosocomial Pneumonia: A Randomized, Controlled Study. Clin Infect Dis 54: 621-629.

12. Fowler VG Jr, Boucher HW, Corey GR, Abrutyn E, Karchmer AW, et al. (2006) Daptomycin versus Standard Therapy for Bacteremia and Endocarditis Caused by Staphylococcus aureus. N Engl J Med 355: 653-665.

13. Verkade EJ, Verhulst CJ, Huijsdens XW, Kluytmans JA (2010) In vitro Activity of Tigecycline against Methicillin-Resistant Staphylococcus aureus including Livestock-associated Strains. Eur J Clin Microbiol Infect Dis 29: 503-507.

14. Saravolatz LD, Stein GE, Johnson LB (2011) Ceftaroline: A Novel cephalosporin with Activity against Methicillin-Resistant Staphylococcus aureus. Clin Infect Dis 52: 1156-1163.
15. Hsu LY, Leong M, Balm M, Chan DS, Huggan P, et al. (2010) Six Cases of Daptomycin- non-susceptible Staphylococcus aureus Bacteremia in Singapore. J Med Microbiol 59: 1509-1513.

16. Sánchez García M, De la Torre MA, Morales G, Peláez B, Tolón MJ, et al. (2010) Clinical Outbreak of Linezolid-Resistant Staphylococcus aureus in an Intensive Care Unit. JAMA 303: 2260-2264.

17. Mendes RE, Tsakris A, Sader HS, Jones RN, Biek D, et al. (2012) Characterization of Methicillin-Resistant Staphylococcus aureus Displaying increased MICs of Ceftaroline. J Antimicrob Chemother.

18. Owens RC Jr, Donskey CJ, Gaynes RP, Loo VG, Muto CA (2008) AntimicrobialAssociated Risk Factors for Clostridium difficile Infection. Clin Infect Dis 46 S19-S31.

19. Soong G, Martin FJ, Chun J, Cohen TS, Ahn DS (2011) Staphylococcus aureus Protein A Mediates Invasion across airway Epithelial Cells through Activation of RhoA GTPase signaling and proteolytic activity. J Biol Chem 286 35891-35898.

20. Lowy I, Molrine DC, Leav BA, Blair BM, Baxter R, et al. (2010) Treatment with Monoclonal Antibodies against Clostridium difficile Toxins. N Engl J Med 362 197-205.

21. Chung EY, Huang L, Schneider L (2010) Safety of Influenza Vaccine Administration in Egg-Allergic Patients. Pediatrics 125: e1024-e1230. 